\title{
Hubungan Lama Ketuban Pecah Dini, Umur ibu, Paritas dan Jenis Persalinan terhadap Nilai APGAR
}

\section{Yessy Octa Fristika \\ STIK Siti Khadijah Palembang}

Informasi Artikel :

Diterima : 31 Maret 2021

Direvisi : 15 April 2021

Disetujui : 29 Mei 2021

Diterbitkan : 15 Juni 2021

\author{
"Korespondensi Penulis \\ yessyocta.fristika@ymail.com
}

\begin{abstract}
A B S T R A K
Ketuban Pecah Dini adalah pecahnya selaput ketuban sebelum adanya tanda persalinan. Ketuban pecah dini merupakan salah satu penyebab terjadinya asfiksia neonatorum dan infeksi yang dapat meningkatkan mortalitas dan morbiditas perinatal. Tujuan penelitian ini untuk mengetahui hubungan antara lama ketuban pecah dini, umur ibu, paritas dan jenis persalinan terhadap nilai APGAR pada kehamilan aterm di RSIA Cinta Kasih Ciputat, Tangerang Selatan periode Januari-Oktober tahun 2012. Metode Penelitian ini menggunakan desain analitik dengan pendekatan cross sectional. Analisa yang digunakan adalah univariat dan bivariat. Jumlah populasinya adalah 245 ibu bersalin dan sampel yang diambil secara simple random sampling yang diambil dari data sekunder rekam medik sebanyak 71 ibu bersalin. Hasil penelitian menunjukkan Ada hubungan yang bermakna antara lama KPD terhadap nilai APGAR yaitu P-Value $=0,001$. Tidak ada hubungan antara umur ibu terhadap nilai APGAR yaitu P-Value = 0,816 . Tidak ada hubungan antara paritas terhadap nilai APGAR yaitu P-Value $=0,203$. Ada hubungan yang bermakna antara Jenis persalinan terhadap nilai APGAR yaitu P-Value $=0,000$. Kesimpulan hasil penelitian ini menunjukkan ada hubungan yang cukup kuat antara Lama KPD dan Jenis Persalinan dengan nilai APGAR.
\end{abstract}

Kata Kunci : KPD, Jenis Persalinan, APGAR

\section{ABSTRACT}

Premature Rupture Of Membrane (PROM) is rupture of the membrane before the onset of labour. PROM is one of the cause from asphyxia neonatorum and infection which can increase mortality and morbidity perinatal. The research objective was to identify the correlation between long premature rupture of membrane, maternal age, parity and kind of labour with APGAR score in the Mother and Child Hospital Cinta Kasih Ciputat, South Tangerang in January-October 2012. The method in this study is cross sectional analytic approach. The analysis used univariate and bivariate. Total population were 245 maternal and samples taken by simple random sampling from secondary data of medical record as much as 71 maternal. The results showed There is a significant correlation between Long PROM with APGAR score with $P$-Value $=0.001$. There is no correlation between maternal age with APGAR score with P-Value $=0,816$. There is no correlation between parity with APGAR score with P-Value = 0,203 . There is a significant correlation between kind of labour with APGAR score with P-Value $=0.000$. The Conclusion of this study showed there is fairly strong correlation between Long PROM and kind of labour with Apgar score.

Keywords $\quad:$ PROM, Kind of Labour, APGAR 


\section{Jurnal Kebidanan : Jurnal Medical Science Ilmu Kesehatan Akademi Kebidanan Budi Mulia \\ Palembang Volume.11 No.1, Juni 2021 \\ Available online http://iournal.budimulia.ac.id/}

\section{PENDAHULUAN}

Ukuran keberhasilan suatu pelayanan kesehatan tercermin dari penurunan angka kematian ibu (Maternity Mortality Rate) sampai pada batas angka terendah yang dapat dicapai sesuai dengan kondisi dan situasi setempat serta waktu. Kematian maternal adalah kematian dari setiap wanita hamil, persalinan dan dalam 42 hari sesudah berakhirnya kehamilan oleh sebab apapun, tanpa memperhitungkan tuanya kehamilan dan tindakan yang dilakukan untuk mengakhiri kehamilan (Prawirohardjo, 2014).

Untuk melihat kecenderungan AKI di Indonesia secara konsisten, digunakan data hasil Survey Demografi dan Kesehatan Indonesia (SDKI). AKI sebesar 359 per 100.000 Kelahiran Hidup (KH) diperoleh dari hasil SDKI 2012 dan berdasarkan data Survey Penduduk Antar Sensus (SUPAS) 2015 AKI sebesar 305 per $100.000 \mathrm{KH}$. Hal ini menunjukkan AKI cenderung terus menurun. Tetapi masih jauh bila dibandingkan dengan target yang ingin dicapai secara nasional, yaitu sebesar 102 per $100.000 \mathrm{KH}$. Kemudian program SDGs mempunyai target untuk mengurangi AKI yaitu 70 per $100.000 \mathrm{KH}$ pada tahun 2030 serta menurunkan AKB setidaknya 12 per $1000 \mathrm{KH}$ (Kemenkes, 2016).

Jumlah kasus kematian ibu di Provinsi Banten pada tahun 2017 sebanyak 226 kasus, Tahun 2018 sebanyak 135 Kasus dan Tahun 2019 sebanyak 215 Kasus. Kabupaten/kota dengan Angka Kematian Bayi tertinggi tahun 2019 adalah Kabupaten Serang sebanyak 273 Bayi. Dan Kabupaten/kota dengan Angka Kematian Bayi paling rendah adalah Kota Cilegon sebanyak 20 Bayi (Dinkes, 2020)

Kematian bayi disebabkan oleh faktor penyebab kematian bayi seperti asfiksia (gangguan pernafasan) pada bayi baru lahir, tingkat pelayanan antenatal care, status gizi ibu hamil, pertolongan persalinan, tingkat keberhasilan program KIA dan KB, serta kondisi lingkungan dan sosial ekonomi.
Jumlah kematian neonatal di Provinsi Banten tahun 2019 sebesar 1.154 per 1.000 kelahiran hidup. Lebih tinggi di banding data tahun 2018 sebesar 822 per 1000 kelahiran hidup. (Dinkes, 2020).

Insidensi KPD berkisar 4,5 \% sampai $7,6 \%$ dari seluruh kehamilan. Insidensi di kalangan wanita yang melahirkan bayi prematur berkisar $40-60 \%$ dan angka kematian perinatal prematur meningkat nyata jika terdapat ketuban pecah dini (KPD). Insidensi terjadinya KPD antara 6\% sampai $19 \%$ (Fadlun dkk, 2011).

Penyebab kematian langsung adalah kematian ibu karena akibat langsung dari penyakit kehamilan, persalinan dan nifas : misalnya infeksi, eklamsia, perdarahan, emboli air ketuban, trauma anastesi, trauma operasi dan lain - lain. Infeksi yang banyak di alami oleh ibu sebagian besar merupakan akibat dari adanya komplikasi/penyulit kehamilan, seperti febris, korioamnionitis, infeksi saluran kemih, dan sebanyak 65\% adalah karena ketuban pecah dini (KPD) yang banyak menimbulkan infeksi pada ibu dan bayi (Prawirohardjo, 2014).

Ketuban pecah dini disebabkan oleh karena berkurangnya kekuatan membran atau meningkatnya tekanan intrauterin atau oleh kedua faktor tersebut. Berkurangnya kekuatan membran disebabkan oleh adanya infeksi yang dapat berasal dari vagina dan serviks (Prawirohardjo, 2014). Ketuban pecah dini merupakan salah satu faktor penyebab asfiksia neonatorum dan infeksi. Hipoksia pada janin yang menyebabkan asfiksia neonatorum terjadi karena gangguan pertukaran transport gas oksigen dari ibu ke janin sehingga terdapat gangguan dalam persediaan oksigen dan dalam menghilangkan karbondioksida. Gangguan ini berlangsung secara menahun akibat kondisi atau kelainan pada ibu selama kehamilan atau secara mendadak karena hal - hal yang diderita pada ibu dalam persalinan (Manuaba, 2015).

Ketuban pecah dini merupakan sumber persalinan prematuritas, infeksi dalam rahim ibu maupun janin yang cukup besar. Oleh karena itu tatalaksana ketuban 


\section{Jurnal Kebidanan : Jurnal Medical Science Ilmu Kesehatan Akademi Kebidanan Budi Mulia \\ Palembang Volume.11 No.1, Juni 2021 \\ Available online http://iournal.budimulia.ac.id/}

pecah dini memerlukan tindakan yang rinci sehingga dapat menurunkan kejadian persalinan prematuritas dan infeksi dalam rahim (Manuaba, 2015). Resiko infeksi ibu dan bayi meningkat pada ketuban pecah dini yang tertunda sampai 24 jam, durasi KPD berhubungan dengan peningkatan kejadian infeksi dan komplikasi lain dari KPD (Hijayati, 2017).

Nilai Apgar adalah penilaian keadaan umum bayi yang dinilai satu menit setelah lahir. Patokan klinis untuk menilai keadaan bayi tersebut adalah frekuensi jantung (heart rate), usaha nafas (respiratory effort), tonus otot (muscle tone), warna kulit (colour) dan refleks atau reaksi terhadap rangsangan (Sumarah dkk, 2015).

Lamanya Ketuban Pecah Dini adalah Jarak waktu antara pecahnya ketuban dan lahirnya bayi. Dari hasil penelitian yang dilakukan oleh Legawati dkk (2018) di Ruang Cempaka RSUD DR Doris Sylvanus Palangkaraya bahwa Kejadian KPD paling banyak terjadi < 12 jam yaitu 145 orang $(87.3 \%)$ dibandingkan dengan kejadian KPD >12 jam yaitu 21 orang (12.7\%) dan penelitian yang dilakukan oleh Anisa (2017) bahwa ibu yang mengalami Ketuban Pecah Dini $\geq 12$ jam mayoritas $(67,2 \%)$ mengalami Asfiksia Neonatorum, sedangkan ibu yang mengalami Ketuban Pecah Dini < 12 jam lebih dari setengah $(55,2 \%)$ tidak mengalami Asfiksia Neonatorum.

Umur Ibu yang lebih tua mungkin menyebabkan ketuban kurang kuat daripada ibu muda sehingga menyebabkan terjadinya ketuban pecah dini (Nugroho, 2012). Berdasarkan hasil penelitian Legawati dkk (2018) di Ruang Cempaka RSUD DR Doris Sylvanus Palangkaraya bahwa Umur Risiko Rendah (20-35 tahun) yang mengalami ketuban pecah dini ada 129 Orang $(77,7 \%)$ dan Umur Risiko Tinggi ( $<20$ tahun dan > 35 tahun) yang mengalami ketuban pecah dini sebanyak 37 Orang (22,3\%).

Paritas ibu semakin banyak jumlah anak yang dilahirkan, potensi kejadian ketuban pecah dini semakin besar. Berdasarkan hasil penelitian Siregar (2011) di RSUD Padang Sidimpuan, yang mengalami ketuban pecah dini periode Januari - Maret ada 47 pasien, dari 47 pasien tersebut, ada 21 orang yang mengalami ketuban pecah dini dengan paritas primipara sedangkan 26 orang multipara, dan penelitian yang dilakukan di RB Riyanti, Maospati Jawa Barat, yang mengalami kejadian ketuban pecah dini berdasarkan faktor paritas yaitu pada multipara sebesar 37,59\%.

Sedangkan kejadian ketuban pecah dini berdasarkan jenis persalinan (spontan atau spontan dengan induksi) yang berpengaruh kepada nilai APGAR yaitu penelitian yang dilakukan oleh Ningrum (2016) di Rumah Sakit Islam Sultan Agung Semarang diperoleh kasus Ketuban Pecah Dini sebanyak 224 orang $(52,7 \%)$ dengan penatalaksanaanya yaitu persalinan spontan sebanyak 109 orang $(48,6 \%)$ terbagi dalam persalinan spontan dengan induksi sebanyak 69 orang $(30,8 \%)$ dan persalinan spontan tanpa induksi sebanyak 40 orang $(17,8 \%)$ sisanya diakhiri dengan program SC (Sectio Caesaria) 115 orang $(51,4 \%)$.

Berdasarkan hasil survey awal yang dilakukan, jumlah seluruh persalinan di RSIA Cinta Kasih Ciputat, Tangerang tahun 2011 sebesar 2551 persalinan, yang mengalami Ketuban Pecah Dini pada Kehamilan Aterm ada 366 orang sedangkan Periode Januari - Oktober pada tahun 2012 sebesar 1359 persalinan, yang mengalami Ketuban Pecah Dini pada Kehamilan Aterm ada 245 orang. Angka kejadian Ketuban Pecah Dini di RSIA Cinta Kasih Ciputat, Tangerang periode Januari - Oktober tahun 2012 ini masih tinggi jika dilihat dari angka kejadian Ketuban Pecah Dini pada penelitian sebelumnya.

Variabel bebas dalam kerangka teori penelitian ini adalah faktor predisposisi (Paritas, Hidramnion, Ketuban Pecah Dini), Faktor ibu (Umur ibu, Penyakit kronis), Faktor Bayi (Kehamilan kembar, Cacat bawaan, IUGR), Faktor Persalinan (Jenis persalinan). Variabel terikat dalam penelitian ini adalah Nilai APGAR (Nugroho, 2012). Variabel bebas dalam 


\section{Jurnal Kebidanan : Jurnal Medical Science Ilmu Kesehatan Akademi Kebidanan Budi Mulia \\ Palembang Volume.11 No.1, Juni 2021 \\ Available online http://iournal.budimulia.ac.id/}

kerangka konsep penelitian ini adalah Lama ketuban pecah dini, umur ibu, paritas dan jenis persalinan. Variabel terikat dalam penelitian ini adalah Nilai APGAR.

Tujuan penelitian ini untuk mengetahui Hubungan antara Lama Ketuban Pecah Dini, Umur Ibu, Paritas dan Jenis Persalinan terhadap Nilai APGAR Pada Kehamilan Aterm di RSIA Cinta Kasih Ciputat, Tangerang periode Januari Oktober Tahun 2012.

\section{METODE PENELITIAN}

Desain penelitian yang digunakan dalam penelitian ini bersifat analitik kuantitatif dengan menggunakan data sekunder yang dilakukan melalui pendekatan cross sectional untuk mengetahui hubungan dari variabel bebas yaitu Lama Ketuban Pecah Dini, Umur Ibu, Paritas dan Jenis Persalinan dengan variabel terikatnya adalah Nilai APGAR.

Lokasi dan waktu penelitian dilakukan di RSIA Cinta Kasih Ciputat, Tangerang selatan pada bulan November Tahun 2012. Populasi dalam penelitian ini adalah seluruh ibu bersalin yang mengalami Ketuban Pecah Dini pada Kehamilan Aterm di RSIA Cinta Kasih Ciputat, Tangerang yaitu sebesar 245 orang dan Sampel yang digunakan yaitu sebagian ibu bersalin yang mengalami Ketuban Pecah Dini pada Kehamilan Aterm di RSIA Cinta Kasih Ciputat, Tangerang yaitu sebesar 71 sampel.

Teknik pengambilan sampel dalam penelitian ini menggunakan metode simple random sampling/acak sederhana. Hakikat dari pengambilan sampel secara acak sederhana adalah bahwa setiap anggota atau unit dari populasi mempunyai kesempatan yang sama untuk diseleksi sebagai sampel (Notoatmodjo, 2012).

Pada penelitian ini instrument yang digunakan dalam pengumpulan data adalah status pasien yang diperoleh dari rekam medik dan lembar cheklist. Pengumpulan data yang digunakan adalah data sekunder yaitu dengan melihat status pasien pada rekam medik di RSIA Cinta Kasih Ciputat,
Tangerang. Setelah dilakukan pengumpulan data, kemudian dilakukan pengolahan data dengan menggunakan komputerisasi yaitu dengan langkah-langkah sebagai berikut: Dilakukan proses editing yaitu pemilihan data di lapangan sehingga dapat menghasilkan data yang lebih akurat untuk pengolahan data selanjutnya. Kegiatan yang dilaksanakan adalah memeriksa kembali kelengkapan data dan dilakukan pengelompokkan data seperti Lama Ketuban Pecah Dini, umur ibu, paritas ibu, tindakan persalinan dan Nilai Apgar. Coding merupakan kegiatan merubah data berbentuk huruf menjadi data berbentuk angka/bilangan. Proses coding digunakan untuk memudahkan dalam mengolah data melalui komputer sesuai dengan definisi operasional. Proccessing yaitu pemrosesan dilakukan dengan mengentry data ke komputer dengan menggunakan komputerisasi. Cleaning (pembersihan data) merupakan kegiatan pengecekan kembali data yang sudah di entry apakah ada kesalahan atau tidak.

Analisa Data yang digunakan dalam penelitian ini yaitu dianalisa dengan 2 cara: Analisa univariat yang dilakukan untuk mengetahui distribusi frekuensi masingmasing variabel yang diteliti dan disajikan dalam bentuk tabel dan Analisa bivariat adalah tabel silang 2 variabel (variabel dependen dan variabel independen). Analisa ini dilakukan untuk melihat kemaknaan hubungan antara variabel dependen dan variabel independen, uji yang digunakan adalah "Kai Kuadrat" dengan menggunakan derajat kepercayaan $95 \%$ dengan derajad kesalahan $\alpha=0,05$. Dengan menggunakan komputerisasi. Penyajian Data dalam penelitian ini disajikan dalam bentuk Tabel dan Narasi.

\section{HASIL PENELITIAN}

Hasil penelitian disajikan dalam bentuk Analisis univariat dan bivariat. Analisis univariat dalam penelitian ini akan menggambarkan distribusi frekuensi dari seluruh variabel Lama Ketuban Pecah Dini, 
Jurnal Kebidanan : Jurnal Medical Science Ilmu Kesehatan Akademi Kebidanan Budi Mulia

Palembang Volume.11 No.1, Juni 2021

Available online http://journal.budimulia.ac.id/

umur ibu, paritas ibu, Jenis Persalinan dan

Nilai APGAR.

\section{a. Analasis Univariat}

Tabel 1 Hasil Univariat

\begin{tabular}{lcc}
\hline \multicolumn{1}{c}{ Variabel } & Gambaran & Presentasi \\
\hline Lama KPD & 48 & $67,6 \%$ \\
$\leq 12$ Jam & 23 & $32,4 \%$ \\
$>$ 12 Jam & & \\
& & \\
Umur Ibu & 57 & $80,3 \%$ \\
$20-35$ tahun & 14 & $19,7 \%$ \\
$<20$ tahun dan $>35$ tahun & & \\
Paritas & 34 & $47,9 \%$ \\
Primipara & 37 & $52,1 \%$ \\
Multipara/grande multipara & & \\
Jenis Persalinan & 32 & $45,1 \%$ \\
Spontan & 39 & $54,9 \%$ \\
Tindakan Induksi & & \\
Nilai APGAR & & $56,3 \%$ \\
APGAR Baik $\geq 7$ & 40 & $43,7 \%$ \\
APGAR Buruk $<7$ & 31 & \\
\hline
\end{tabular}

Berdasarkan tabel 1, Lama Ketuban Pecah Dini $\leq 12$ Jam yaitu sebanyak $48 \mathrm{ibu}$ bersalin $(67,6 \%)$ dan Lama Ketuban Pecah Dini > 12 Jam sebesar $23 \mathrm{ibu}$ bersalin $(32,4 \%)$, Umur ibu yang mempengaruhi nilai Apgar terbanyak ditemukan pada kelompok umur 20-35 tahun yaitu sebesar 57 ibu bersalin $(80,3 \%)$ sedangkan kelompok umur $<20$ tahun dan $>35$ tahun sebesar 14 ibu bersalin (19,7\%). Paritas ibu yang terbanyak mengalami ketuban pecah dini dan berpengaruh terhadap nilai apgar yaitu pada kelompok Multipara/grande multipara sebesar $37 \mathrm{ibu}$ bersalin $(52,1 \%)$ sedangkan pada kelompok Primipara sebesar $34 \mathrm{ibu}$ bersalin $(47,9 \%)$. Jenis Persalinan yang mempengaruhi nilai apgar adalah Persalinan dengan tindakan induksi yaitu sebanyak 39 ibu bersalin $(54,9 \%)$ sedangkan persalinan dengan spontan sebanyak $32 \mathrm{ibu}$ bersalin $(45,1 \%)$. Nilai
APGAR terbanyak yaitu nilai APGAR $\geq 7$ yang artinya nilai APGAR baik sebanyak 40 orang $(56,3 \%)$ sedangkan nilai APGAR $<7$ yang artinya nilai APGAR buruk sebanyak 31 orang $(43,7 \%)$.

\section{b. Analisis Bivariat}

Analisa bivariat digunakan untuk membuktikan adanya hubungan antara variabel independen (Lama ketuban pecah dini, umur ibu, paritas, jenis persalinan) dengan variabel dependen (nilai APGAR) seperti yang dinyatakan dalam hipotesis penelitian. Uji statistik yang digunakan adalah uji chi square $\left(X^{2}\right)$ dengan derajat kemaknaan sebesar 5\%. Penyajian analisis secara berturut-turut dimulai dari Lama Ketuban Pecah Dini, Umur ibu, paritas, dan Jenis Persalinan dengan Nilai Apgar pada kehamilan aterm sebagai berikut 


\section{Jurnal Kebidanan : Jurnal Medical Science Ilmu Kesehatan Akademi Kebidanan Budi Mulia \\ Palembang Volume.11 No.1, Juni 2021 \\ Available online http://iournal.budimulia.ac.id/}

Tabel 2 Hasil Bivariat Hubungan Lama Ketuban Pecah Dini, Umur ibu, Paritas dan Jenis Persalinan terhadap Nilai APGAR

\begin{tabular}{|c|c|c|c|c|c|c|c|c|c|}
\hline \multirow[t]{3}{*}{ Variabel } & \multirow{3}{*}{$\begin{array}{l}\text { Hasil } \\
\text { Ukur }\end{array}$} & \multicolumn{4}{|c|}{ Nilai APGAR } & \multirow{2}{*}{\multicolumn{2}{|c|}{ Total }} & \multirow{3}{*}{$\begin{array}{c}\text { P - } \\
\text { Value }\end{array}$} & \multirow{3}{*}{$\begin{array}{c}\text { OR } \\
(95 \% \\
\text { CI })\end{array}$} \\
\hline & & \multicolumn{2}{|c|}{$\geq 7$} & \multicolumn{2}{|c|}{$<7$} & & & & \\
\hline & & Jumlah & $\%$ & Jumlah & $\%$ & Jumlah & $\%$ & & \\
\hline Lama & $\leq 12 \mathrm{Jam}$ & 34 & $70,8 \%$ & 14 & $29,2 \%$ & 48 & 100 & & 6,881 \\
\hline $\begin{array}{c}\text { Ketuban } \\
\text { Pecah } \\
\text { Dini }\end{array}$ & $>12 \mathrm{Jam}$ & 6 & $26,1 \%$ & 17 & $73,9 \%$ & 23 & 100 & 0,001 & $\begin{array}{l}(2,246- \\
21,081)\end{array}$ \\
\hline \multirow[t]{2}{*}{ Umur Ibu } & $\begin{array}{c}20-35 \\
\text { tahun }\end{array}$ & 33 & $57,9 \%$ & 24 & $42,1 \%$ & 57 & 100 & \multirow{2}{*}{0,816} & $\begin{array}{r}1,375 \\
(0,426-\end{array}$ \\
\hline & $\begin{array}{c}<20 \text { dan } \\
>35 \text { tahun }\end{array}$ & 7 & $50,0 \%$ & 7 & $50,0 \%$ & 14 & 100 & & $4,440)$ \\
\hline \multirow[t]{2}{*}{ Paritas } & Primipara & 16 & $47,1 \%$ & 18 & $52,9 \%$ & 34 & 100 & \multirow[b]{2}{*}{0,203} & 0,481 \\
\hline & $\begin{array}{l}\text { Multipara/ } \\
\text { grande } \\
\text { multipara }\end{array}$ & 24 & $64,9 \%$ & 13 & $35,1 \%$ & 37 & 100 & & $\begin{array}{c}(0,186- \\
1,249\end{array}$ \\
\hline Jenis & Spontan & 27 & $84,4 \%$ & 5 & $15,6 \%$ & 32 & 100 & & 10,800 \\
\hline Persalinan & $\begin{array}{c}\text { Tindakan } \\
\text { Induksi }\end{array}$ & 13 & $33,3 \%$ & 26 & $66,7 \%$ & 39 & 100 & 0,000 & $\begin{array}{l}(3,374- \\
34,573)\end{array}$ \\
\hline
\end{tabular}

Berdasarkan tabel 2, Hasil analisis hubungan antara Lama Ketuban Pecah Dini dengan Nilai APGAR, dari 48 ibu bersalin yang mengalami Lama Ketuban Pecah Dini $\leq 12$ Jam, didapatkan bayi dengan nilai APGAR baik $\geq 7$ sebesar 34 bayi $(70,8 \%)$ dan APGAR buruk <7 sebesar 14 bayi $(29,2 \%)$ dan dari 23 ibu bersalin yang berusia yang mengalami Lama Ketuban Pecah Dini >12 Jam, didapatkan bayi dengan nilai APGAR baik $\geq 7$ sebesar 6 bayi $(26,1 \%)$ dan APGAR buruk $<7$ sebesar 17 bayi $(73,9 \%)$. Hasil uji statistik chi square diperoleh nilai $\mathrm{P}-\mathrm{Value}=0,001$ (P-Value $<\alpha$ ), berarti pada $\alpha=5 \%$ menunjukkan bahwa ada hubungan yang bermakna antara Lama Ketuban Pecah Dini terhadap Nilai APGAR. Analisa hubungan dua variabel didapatkan $\mathrm{OR}=6,881(95 \%$ CI : 2,246-21,081). Hal ini menunjukkan bahwa ibu yang mengalami Ketuban Pecah Dini $\leq 12$ Jam memiliki peluang untuk mendapat Nilai APGAR baik $\geq 7$ 6,881 kali dibandingkan dengan ibu yang mengalami Ketuban Pecah Dini >12 Jam.
Hasil analisis hubungan antara Umur Ibu dengan Nilai APGAR, dari 57 ibu yang berusia 20-35 tahun, didapatkan nilai APGAR baik $\geq 7$ sebanyak 33 bayi $(57,9 \%)$ dan nilai APGAR buruk <7 sebanyak 24 bayi $(42,1 \%)$ dan dari 14 ibu yang berusia $<20$ tahun dan $>35$ tahun, didapatkan nilai APGAR $\geq 7$ sebanyak 7 bayi $(50,0 \%)$ dan APGAR buruk $<7$ sebanyak 7 bayi (50,0\%). Hasil uji statistik chi square diperoleh nilai $\mathrm{P}-$ Value $=0,816(\mathrm{P}-$ Value $>$ $\alpha)$ berarti pada $\alpha=5 \%$ menunjukkan bahwa tidak ada hubungan yang bermakna antara umur ibu dengan nilai APGAR.

Hasil analisis hubungan antara Paritas dengan Nilai APGAR, dari 37 ibu bersalin dengan paritas Multipara/grande multipara, didapatkan nilai APGAR baik $\geq 7$ sebanyak 24 bayi $(64,9 \%)$ dan APGAR buruk $<7$ sebanyak 13 bayi $(35,1 \%)$ dan dari 34 ibu bersalin dengan paritas primipara, didapatkan nilai APGAR baik $\geq 7$ sebanyak 16 bayi $(47,1 \%)$ dan APGAR buruk <7 sebanyak 18 bayi $(52,9 \%)$. Hasil uji statistik chi square diperoleh nilai P-Value $=0,203(\mathrm{P}-$ Value $>\alpha)$, berarti pada $\alpha=5 \%$ 
menunjukkan bahwa tidak ada hubungan yang bermakna antara paritas dengan nilai APGAR.

Hasil analisis hubungan antara Jenis Persalinan dengan Nilai APGAR, dari 39 ibu bersalin dengan persalinan tindakan induksi, didapatkan bayi dengan nilai APGAR baik $\geq 7$ sebanyak 13 ibu bersalin $(33,3 \%)$ dan nilai APGAR buruk $<7$ sebanyak $26 \mathrm{ibu}$ bersalin $(66,7 \%)$ dan dari 32 ibu bersalin dengan persalinan spontan, didapatkan bayi dengan nilai APGAR baik $\geq 7$ sebanyak 27 bayi $(84,4 \%)$ dan APGAR buruk $<7$ sebanyak 5 bayi $(15,6 \%)$. Hasil uji statistik chi square diperoleh nilai $\mathrm{P}$ Value $=0,000(\mathrm{P}-$ Value $<\alpha)$ berarti pada $\alpha$ $=5 \%$ menunjukkan bahwa Ada Hubungan yang bermakna antara jenis persalinan dengan nilai APGAR. Analisa hubungan dua variabel didapatkan OR $=10,800(95 \%$ CI : 3,374 - 34,573). Hal ini menunjukkan bahwa jenis persalinan spontan memiliki peluang untuk mendapat Nilai APGAR baik $\geq 7 \quad 10,800$ kali dibandingkan dengan persalinan dengan tindakan induksi.

\section{PEMBAHASAN}

Pembahasan hasil penelitian ini menguraikan tentang hasil penelitian dengan konsep terkait dan hasil penelitian terdahulu. Hasil penelitian ini secara umum sudah menjawab pertanyaan sesuai dengan tujuan penelitian yaitu untuk mengetahui Hubungan Antara Lama Ketuban Pecah Dini, Umur ibu, paritas dan Jenis Persalinan terhadap Nilai APGAR Pada Kehamilan Aterm di RSIA Cinta Kasih Ciputat, Tangerang Selatan periode Januari - Oktober 2012, setelah dilakukan uji statistik bivariat diperoleh sebagai berikut :

\section{Lama Ketuban Pecah Dini}

Sebagian besar ibu bersalin mengalami lama ketuban pecah dini $\leq 12$ Jam. Hasil uji statistik chi square diperoleh $\mathrm{P}$-Value $=0,001(\mathrm{P}-$ Value $<\alpha)$ dan $\mathrm{OR}=$ 6,881 (95\% CI : 2,246 - 21,081). Hal ini menunjukkan bahwa Ada hubungan yang bermakna antara Lama Ketuban Pecah Dini terhadap Nilai APGAR.
Hasil penelitian ini sesuai dengan hasil penelitian yang dilakukan oleh Legawati dkk (2018) di Ruang Cempaka RSUD DR Doris Sylvanus Palangkaraya bahwa Kejadian Ketuban Pecah Dini paling banyak terjadi <12 jam yaitu 145 orang $(87.3 \%)$ dibandingkan dengan kejadian Ketuban Pecah Dini >12 jam yaitu 21 orang $(12.7 \%)$ dan penelitian yang dilakukan oleh Anisa (2017) bahwa ibu yang mengalami Ketuban Pecah Dini $\geq 12$ jam mayoritas $(67,2 \%)$ mengalami Asfiksia Neonatorum, sedangkan ibu yang mengalami Ketuban Pecah Dini < 12 jam lebih dari setengah $(55,2 \%)$ tidak mengalami Asfiksia Neonatorum. Penelitian ini menunjukkan hubungan antara Lama KPD dan Nilai APGAR.

Hasil penelitian ini juga sesuai dengan hasil penelitian yang dilakukan oleh Anggraeni dkk (2020) bahwa Durasi KPD $<12$ jam didapatkan skor APGAR sedang 12 kasus $(10,71 \%)$ dan skor APGAR normal sebanyak 64 kasus $(57,14 \%)$, sedangkan KPD dengan durasi $>12$ jam didapatkan skor APGAR berat 2 kasus $(1,79 \%)$, skor APGAR sedang 24 kasus $(21,43 \%)$ dan skor APGAR normal 36 kasus $(32,14 \%)$. Analisis bivariat menggunakan uji ChiSquare diperoleh nilai $\mathrm{p}=0,000(\mathrm{p}<0,05)$. Terdapat hubungan antara durasi ketuban pecah dini dengan APGAR skor neonatus.

Hasil Penelitian ini juga didukung oleh teori Mochtar (2011) yang mengatakan bahwa Ketuban Pecah Dini (KPD) adalah pecahnya selaput ketuban sebelum ada tanda-tanda persalinan, insiden dari KPD adalah $12 \%$ dari seluruh kehamilan. Penyebab dari KPD masih belum jelas, maka tindakan preventive tidak dapat dilakukan, kecuali dalam usaha menekan terjadinya infeksi. Walaupun ketuban sering pecah spontan sebelum persalinan semakin lama selaput tersebut pecah sebelum kelahiran akan semakin besar resiko infeksi kepada janin maupun ibunya. dan sesuai dengan teori Prawirohardjo (2014) yang mengatakan bahwa Ketuban pecah dini merupakan salah satu faktor penyebab asfiksia neonatorum dan infeksi, dimana 
asfiksia neonatorum ini adalah keadaan dimana bayi tidak dapat bernafas secara spontan dan teratur segera setelah lahir.

Penelitian ini juga didukung teori Endale, dkk (2016) yang menyatakan bahwa bayi yang lahir dari ibu yang mengalami KPD > 12 jam beresiko 12 kali lebih besar untuk mengalami kondisi yang buruk bagi bayi darpada bayi yang lahir dengan durasi KPD <12 jam yakni diantaranya ialah APGAR Skor neonatus yang lebih buruk, salah satu kondisi yang kurang baik yakni tingkat asfiksia bayi yang berat.

Namun, hasil penelitian ini tidak sesuai dengan hasil penelitian yang dilakukan oleh Syarwani, dkk (2018) bahwa APGAR score terbanyak didapatkan pada bayi dengan ibu yang mengalami KPD yaitu nilai APGAR 7-10 (79,48\%).

Ketuban pecah dini adalah pecahnya ketuban sebelum waktunya melahirkan / sebelum inpartu, ketuban pecah dini mempunyai kontribusi yang besar pada angka kematian perinatal. Oleh karena itu sebelum ketuban pecah dini ini terjadi maka upaya yang dilakukan adalah mencegahnya. Pencegahan ketuban pecah dini diutamakan dengan menghindari faktor resikonya seperti : Pemeriksaan kehamilan (ANC) yang teratur, Kebiasaan hidup sehat, seperti mengkonsumsi makanan yang sehat, minum cukup, olahraga teratur dan berhenti merokok, Dianjurkan bagi ibu hamil untuk mengurangi aktivitas pada akhir trimester kedua dan awal trimester ketiga, serta tidak melakukan kegiatan yang membahayakan kandungan selama kehamilan, Membiasakan diri membersihkan daerah kemaluan dengan benar, yakni dari depan ke belakang, terutama setelah berkemih atau buang air besar, Memeriksakan diri ke dokter/bidan bila ada sesuatu yang tidak normal di daerah kemaluan, misalnya keputihan yang berbau atau berwarna tidak seperti biasanya, keluar cairan dari vagina dengan bau yang khas, Jika terjadi ketuban pecah dini maka penanganan harus dilakukan dengan segera agar tidak terjadi
APGAR score yang buruk pada bayi baru lahir.

\section{Umur Ibu}

Umur ibu yang mempengaruhi nilai APGAR terbanyak ditemukan pada kelompok umur 20-35 tahun. Hasil uji statistik chi square menunjukkan bahwa Tidak ada hubungan yang bermakna antara umur ibu dengan nilai APGAR. P-Value = $0,816(\mathrm{P}-$ Value $>\alpha)$ dengan $\alpha=5 \%$.

Hasil penelitian ini sesuai dengan hasil penelitian Legawati, dkk (2018) di Ruang Cempaka RSUD DR Doris Sylvanus Palangkaraya bahwa Umur Risiko Rendah (20-35 tahun) yang mengalami ketuban pecah dini ada 129 Orang $(77,7 \%)$ dan Umur Risiko Tinggi (< 20 tahun dan $>35$ tahun) yang mengalami ketuban pecah dini sebanyak 37 Orang $(22,3 \%)$.

Hasil penelitian ini juga didukung oleh Teori Hurlock (2012) yang mengatakan bahwa usia reproduktif (20-30 tahun) terjadi kesiapan respon maksimal baik dalam hal mempelajari sesuatu atau dalam menyesuaikan hal-hal tertentu dan setelah itu sedikit demi sedikit menurun seiring dengan bertambahnya umur. Selain itu pada usia reproduktif mereka lebih terbuka terhadap orang lain dan biasanya mereka akan saling bertukar pengalaman tentang hal yang sama yang pernah mereka alami.

Namun, hasil penelitian ini tidak sesuai dengan Teori Pieter (2011) yang mengatakan bahwa bertambah tuanya usia ibu dapat memperbesar terjadinya bahaya fisik selama periode prenatal dan akan mengalami komplikasi saat melahirkan daripada ibu muda

Umur ibu yang $\leq 20$ tahun, termasuk usia yang terlalu muda dengan keadaan uterus yang kurang matur untuk melahirkan sehingga rentan mengalami ketuban pecah dini. Sedangkan ibu dengan umur $\geq 35$ tahun tergolong usia yang terlalu tua untuk melahirkan khususnya pada ibu primi (tua) dan beresiko tinggi mengalami ketuban pecah dini. Usia dan 
fisik wanita sangat berpengaruh terhadap proses kehamilan pertama, pada kesehatan janin dan proses persalinan. Beberapa resiko yang bisa terjadi pada kehamilan di umur kurang dari 20 tahun adalah kecenderungan naiknya tekanan darah dan pertumbuhan janin terhambat. Bisa jadi secara mental pun wanita belum siap. Ini menyebabkan kesadaran untuk memeriksakan diri dan kandungannya menjadi rendah. Berbeda dengan wanita usia 20-30 tahun yang dianggap ideal untuk menjalani kehamilan dan persalinan. Di rentang usia ini kondisi fisik wanita dalam keadaan prima. Rahim sudah mampu memberi perlindungan atau kondisi yang maksimal untuk kehamilan. Umumnya secara mental pun siap, yang berdampak pada perilaku merawat dan menjaga kehamilannya secara hati-hati.

\section{Paritas}

Paritas ibu yang terbanyak mengalami ketuban pecah dini dan berpengaruh terhadap nilai APGAR yaitu pada kelompok Multipara/grande multipara. Hasil uji statistik chi square diperoleh nilai P-Value $=0,203(\mathrm{P}-$ Value $>\alpha)$, dengan $\alpha=5 \%$ menunjukkan bahwa tidak ada hubungan yang bermakna antara paritas dengan nilai APGAR.

Hasil penelitian ini sesuai dengan hasil penelitian Siregar tahun (2011) di RSUD Padang Sidimpuan, yang mengalami ketuban pecah dini periode Januari - Maret ada 47 pasien, dari 47 pasien tersebut, ada 21 orang yang mengalami ketuban pecah dini dengan paritas primipara sedangkan 26 orang multipara, dan penelitian yang dilakukan di RB Riyanti, Maospati Jawa Barat, yang mengalami kejadian ketuban pecah dini berdasarkan faktor paritas yaitu pada multipara sebesar $37,59 \%$.

Hasil penelitian ini juga sesuai dengan hasil penelitian Atik tahun (2011) di Ruang VK RS Bhakti Rahayu Surabaya bahwa dari 80 responden, didapatkan sebagian besar $(53,8 \%)$ adalah multipara, sebagian besar $(53,5 \%)$ tidak mengalami ketuban pecah dini dan hampir setengah
(36,3\%) yang mengalami ketuban pecah dini. Kesimpulan penelitiannya adalah paritas tinggi berpotensi mengalami kejadian ketuban pecah dini.

Hasil penelitian ini didukung oleh teori Cunningham (2013) yang mengatakan bahwa multipara adalah wanita yang telah beberapa kali mengalami kehamilan dan melahirkan anak hidup. Wanita yang telah melahirkan beberapa kali dan mengalami ketuban pecah dini pada kehamilan sebelumnya serta jarak kelahiran yang terlampau dekat, diyakini lebih beresiko akan mengalami ketuban pecah dini pada kehamilan berikutnya. Meski bukan faktor tunggal penyebab ketuban pecah dini namun faktor ini juga diyakini berpengaruh terhadap terjadinya ketuban pecah dini.

Hasil penelitian ini tidak sesuai dengan hasil penelitian Suriani di RSUD Syekh Yusuf Kabupaten Gowa tahun 2012 bahwa yang mengalami KPD lebih besar pada proporsi ibu beresiko yaitu paritas $<1$ dan $>3$ sebesar 99 orang $(78,0 \%)$ dibandingkan dengan ibu yang jumlah paritasnya 2-3 sebesar 28 orang $(22,0 \%)$ Maka jumlah paritas bukan merupakan faktor risiko terhadap KPD, Meskipun tidak bermakna secara statistik, namun terlihat kecendrungan risiko KPD yaitu 1,5 kali lebih besar pada ibu yang memiliki jumlah paritas risiko tinggi $(<1$ dan $>3)$ dibandingkan ibu yang memiliki jumlah paritas risiko rendah (2-3).

Wanita yang telah melahirkan beberapa kali dan memiliki riwayat ketuban pecah dini pada kehamilan sebelumnya serta jarak anak yang dekat, lebih beresiko akan mengalami ketuban pecah dini pada kehamilan berikutnya. Selain itu faktor lain seperti: keputihan, stress (beban psikologis) saat hamil dan hal lain yang memperberat kondisi ibu dan menyebabkan ketuban pecah dini. Wanita yang mengalami ketuban pecah dini pada kehamilan atau menjelang persalinan maka pada kehamilan berikutnya wanita yang telah mengalami ketuban pecah dini akan lebih beresiko mengalaminya kembali antara 3-4 kali dari pada wanita yang tidak mengalami ketuban 
pecah dini sebelumnya, karena komposisi membran yang menjadi mudah rapuh dan kandungan kolagen yang semakin menurun pada kehamilan berikutnya.

\section{Jenis Persalinan}

Jenis Persalinan yang mempengaruhi nilai APGAR adalah Persalinan dengan tindakan induksi. Hasil uji statistik chi square diperoleh nilai $\mathrm{P}-\mathrm{Value}=0,000(\mathrm{P}$ Value $<\alpha$ ) dengan $\alpha=5 \%$ dan OR $=$ $10,800 \quad(95 \%$ CI : 3,374 - 34,573) menunjukkan bahwa Ada Hubungan yang bermakna antara tindakan persalinan dengan nilai APGAR.

Hasil penelitian ini sesuai dengan teori Nugroho (2012) yang mengatakan bahwa Pada pasien dengan KPD pada kehamilan aterm, direkomendasikan induksi persalinan. Induksi persalinan harus sudah dilakukan dalam $6-12$ jam KPD, jika mungkin dilakukan lebih awal. Oksitosin lebih aman pada usia kehamilan aterm dengan KPD dan sesuai dengan teori Prawirohardjo (2014) yang mengatakan bahwa induksi persalinan adalah usaha agar persalinan mulai berlangsung sebelum atau sesudah kehamilan cukup bulan dengan jalan merangsang timbulnya his, induksi persalinan dapat dilakukan pada rhesusantagonimus, diabetes mellitus, Ketuban Pecah Dini tanpa timbulnya his, dan pada beberapa kelainan - kelainan lain.

Hasil Penelitian ini tidak sesuai dengan hasil penelitian Ningrum (2016) di Rumah Sakit Islam Sultan Agung Semarang diperoleh kasus Ketuban Pecah Dini sebanyak 224 orang $(52,7 \%)$ dengan penatalaksanaanya yaitu persalinan spontan sebanyak 109 orang $(48,6 \%)$ terbagi dalam persalinan spontan dengan induksi sebanyak 69 orang $(30,8 \%)$ dan persalinan spontan tanpa induksi sebanyak 40 orang $(17,8 \%)$ sisanya diakhiri dengan program SC (Sectio Caesaria) 115 orang $(51,4 \%)$. Kesimpulan dari penelitiannya bahwa pasien dengan KPD paling banyak bersalin dengan SC. Dan penelitian ini juga tidak sesuai dengan penelitian Syarwani (2016) bahwa distribusi kasus KPD terbanyak pada jenis persalinan seksio sesarea yaitu 67 kasus.

Induksi diperlukan untuk memperbaiki his pada persalinan dengan ketuban yang sudah lama pecah diharapkan untuk mempercepat persalinan guna menyelamatkan bayi yang ada didalam rahim. Mengingat proses yang cepat untuk persalinan setelah ketuban pecah dini pada masa aterm, manajemen yang dilakukan adalah untuk meminimalkan resiko infeksi intrauterin tanpa peningkatan insidensi persalinan Caesar adalah dengan tindakan induksi, namun tindakan induksi ini harus sesuai dengan penentuan indikasi, pelaksanaan dan pengawasan dilakukan dengan baik.

\section{KESIMPULAN}

Berdasarkan penelitian yang dilakukan,diperoleh dari hasil penelitian telah sesuai dengan tujuan khusus yaitu mengetahui hubungan antara Lama Ketuban Pecah Dini, Umur ibu, Paritas dan Tindakan Persalinan terhadap Nilai APGAR pada Kehamilan Aterm di RSIA Cinta Kasih Ciputat, Tangerang Selatan Periode Januari - Oktober Tahun 2012 dan hubungan dari masing-masing variabel yang diteliti, maka penulis mengambil kesimpulan bahwa Lama Ketuban Pecah Dini dan Tindakan Persalinan memiliki hubungan yang bermakna terhadap Nilai APGAR.

\section{DAFTAR PUSTAKA}

Andini Kartika S, Yudhiakuari Sincihu, B. Triagung Ruddy. 2018. Tingkat Asfiksia Neonatorum Berdasarkan Lamanya Ketuban Pecah Dini pada Persalinan Aterm. Jurnal Kedokteran Wijaya Kusuma. [Di akses pada tanggal 12 Maret 2021] https://journal.uwks.ac.id/index.php/ji kw/article/view/320

Anisa, Ferawati Nur. 2017. Hubungan Lama Ketuban Pecah Dini Dengan Kejadian Asfiksia Neonatorum Di Rsud Wonosari Kabupaten 
Gunungkidul Tahun 2017. [Di akses pada tanggal 12 Maret 2021] http://eprints.poltekkesjogja.ac.id/170 1/1/Naskah\%20Skripsi_Ferawati\%20 Nur\%20Anisa.pdf

Anggraeni, Novia dkk. 2020. Hubungan antara Durasi Ketuban Pecah Dini dengan APGAR Skor Neonatus. [Di akses pada tanggal 12 Maret 2021] https://www.jurnal.fk.umi.ac.id/index. php/umimedicaljournal/article/downlo $\mathrm{ad} / 117 / 85$

Atik, Lina Ihda Kumala. 2011. Hubungan antara paritas dengan kejadian ketuban pecah dini di Ruang VK RS Bhakti Rahayu Surabaya tahun 2011. [Di akses pada tanggal 22 Oktober 2012]

http://share.stikesyarsis.ac.id/elib/mai n/dok/00157/Hubungan-Antara-

Paritas-dengan-Kejadian-Ketuban-

Pecah-Dini-di-Ruang-Vk-RS-BhaktiRahayu-Surabaya.

Cunningham. 2013. Obstetri Williams. Jakarta : EGC

Dinkes. 2020. Profil Kesehatan Provinsi Banten Tahun 2020. [Di akses pada tanggal 12 Maret 2021]. https://dinkes.bantenprov.go.id/read/p rofil-kesehatan-provinsibant/198/Profil-Kesehatan-ProvinsiBanten-Tahun-2020.html.

Endale T, Fentahun N, Gemada D, and Hussen MA. 2016. Maternal and Fetal Outcomes in Term Premature Rupture of Membrane. World $\mathrm{J}$ Emerg Med.

Fadlun, dkk. 2011. Asuhan Kebidanan Patologis. Jakarta: Salemba Medika.

Hijayati, Niang Sukma. 2017. Hubungan Ketuban Pecah Dini (KPD) dengan Kejadian Partus Lama di Rsu Dewi Sartika Provinsi Sulawesi Tenggara.
[Di akses pada tanggal 18 Maret 2021] http://repository.poltekkeskdi.ac.id/23/1/NIANG\%20PDF.pdf

Hurlock. 2012. Faktor yang berhubungan dengan ketuban pecah dini. [Di akses pada tanggal 17 Oktober 2012] http://downloadgratis-sy-

blogspot.com/2010/02/faktor-faktoryang-berhubungan-dengan.html.

Kemenkes. 2016. Undang - Undang Lindungi Hak Anak untuk Dapatkan Pelayanan Kesehatan. [Di akses pada tanggal 18 Maret 2021] https://www.kemkes.go.id/article/prin t/16051800001/undang-undanglindungi-hak-anak-untuk-dapatkanpelayanan-kesehatan.html

Legawati, dkk. 2018. Determinan Kejadian Ketuban Pecah Dini (KPD) Ruang Cempaka RSUD DR Doris Sylvanus Palangkaraya. [Di akses pada tanggal 18 Maret 2021] https://media.neliti.com/media/public ations/258707-determinan-kejadianketuban-pecah-dini-k-5f2e9bf0.pdf

Manuaba, Ida Bagus Gde. 2015. Buku Ajar Phantoom Obstetri Edisi Revisi. Jakarta: EGC.

Mochtar, Rustam. 2011. Sinopsis obstetri. jilid I. 2nd ed. Lutan D, Editors. Jakarta : EGC

Ningrum, Tresna Prasetia. 2016. Asuhan Kebidanan Ibu Bersalin Pada Ny. S Dengan Ketuban Pecah Dini Di Rumah Sakit Islam Sultan Agung Semarang. [Di akses pada tanggal 18 Maret 2021] http://repository.unissula.ac.id/6131/5 /BAB\%20I.pdf

Notoatmodjo, Soekidjo. 2012. Metodologi Penelitian Kesehatan. Jakarta : Rineka Cipta. 
Nugroho, dr. Taufan. 2012. Patologi Kebidanan. Yogyakarta : Nuha Medika.

Nugroho, dr. Taufan. 2012. Obgyn : Obstetri dan Ginekologi. Yogyakarta : Nuha Medika.

Pieter, dkk. 2011. Psikologi Untuk Kebidanan, Jakarta : Kencana.

Prawirohardjo, Sarwono. 2014. Ilmu Kebidanan. Jakarta : Yayasan Bina Pustaka.

Siregar, Fitri Amelia. 2011. Faktor-faktor yang mempengaruhi kejadian ketuban pecah dini di Rumah Sakit Umum Padangsidimpuan. [Di akses pada tanggal 22 Oktober 2012] http://repository.usu.ac.id/handle/123 $456789 / 24515$.

Sumarah, dkk. 2015. Perawatan Ibu Bersalin (Asuhan Kebidanan Pada Ibu Bersalin) .Yogyakarta : Fitramaya.

Suriani, Tahir dkk. 2012. Faktor Determinan Ketuban Pecah Dini Di Rsud Syekh Yusuf Kabupaten Gow. [Di akses pada tanggal 22 Oktober 2012]

http://pasca.unhas.ac.id/jurnal/files/ab dbde934df5c895d7deebd756ce04e1.p df

Syarwani, Teuku I, dkk. 2018. Gambaran Kejadian Ketuban Pecah Dini (KPD) di RSUP Prof. Dr. R.D. Kandou Manado Tahun 2018. [Di akses pada tanggal 18 Maret 2021] https://ejournal.unsrat.ac.id/index.php /msj/article/download/27462/27019 
